\author{
André Kaboré Pacéré as the demiurge of orature \\ André Kaboré is a Ph.D. candidate at \\ the National University of Ireland, \\ Maynooth, Ireland. \\ E-mail:kaboreandre@hotmail.com
}

\title{
Pacéré as the demiurge of orature
}

Not all unwritten literatures are oral literatures. They would more appropriately be referred to as "spoken literatures", in the wider sense of literatures that use different means of communication (mouth, gestures, body movement, instruments). The dumb "speak" with signs. Pio Zirimu proposed the term "orature" to palliate the alleged contradiction in the phrase "oral literature" or "spoken literature". However, as a result of in-depth studies that revealed that before writing, there was a literature, which was spoken, many literary critics prefer the traditional phrase "oral literature" instead of the suggested term "orature". The term "orature" has been taken up in performance studies to designate a genre of written literature at the cusp between spoken and written literatures, referring to written fictions that mix different performing genres. This paper aims at defining orature with an illustration from the poetry of Frédéric Titinga Pacéré and, consequently, to present him as the demiurge of this innovative genre in emerging Burkinabè literature. The implications of the genre of orature are manifold. Orature calls for a redefinition of literature as whatever a given society considers as literature. It demands an interpretation of literature based on an understanding of culture. Key words: Orature, written and spoken literatures, F. T. Pacéré.

\section{Introduction}

Amadou Hampâté Bâ once said in 1962 before a meeting of Unesco: "in Africa, an old man who dies is a library that burns". This saying expresses the fragility of spoken literature. By "spoken" is meant all unwritten ways of communication through mouth, gestures, body movement and instruments. Oral literature is included in spoken literature. Writing and print operated as a remedy for forgetfulness in spoken literature. Printed literature appeared as a subset of and support to spoken literature. However, though the advantage of writing lies in it being an instrument against forgetfulness, the fact is that an event written down on paper but never read or subsequently destroyed is similar to a story that is orally told and then forgotten by both the audience and the teller. So, there are cases where print fails to close the gaps left by spoken literature. It is then that orature comes into play as a necessary connector between print and spoken literatures.

Some writers use different methods to transcribe spoken literature into print as support to performance. Pacéré is one of them. He is the demiurge or creator of a new kind of print literature, orature. The present paper aims at a definition of the concept 
of "orature," as well as its application to Pacéré's Des entrailles de la terre ("From the womb of the earth", 2000).

\section{Definition of orature}

Ngugi wa Thiong' o (1986: 12, 15, 16, 87, 94-95), the Kenyan writer and critic, uses the term "orature" in his writings as a synonym of the traditional phrase "oral literature". Pio Zirimu originally coined the term "orature" in the 1970s as a substitute to palliate the alleged contradiction apparent in the phrase "oral literature" (see Mwangi 2003, Mwangola 2003). However, the rediscovery of oral literature as the antecedent of written literature (see Kesteloot 2001: 13; Rousseau, 1983; Plato 1973: 95-99) accounts for the persistence of some literary critics in the use of "oral literature" instead of "orature" (Ricard 1995: 46). Thus abandoned as an alternative for "oral literature", the term "orature" has been given another meaning. Mshai Mwangola (2003) says that orature has since been re-conceptualized, to mean "an interdisciplinary aesthetic system weaving together numerous genres in the performance of a concept". Orature mixes different performing genres in one. The same literary work can be poetry, sung music, story and drama at the same time.

Joseph Roach (1996: 11-12) defines orature, in the field of performance studies, as a literary genre at the cusp between spoken literature and written literature, highlighting the interaction of these modes of communication over time. Orature is a type of print literature, originally drawn from spoken literature and which is called to return to spoken literature through performance. Mixture or hybridity is one of the identifying features of works of orature. Works of orature mix both spoken and written forms as well as many genres.

Orature brings together the live, dynamic, flexible, repetitive and mnemonic qualities of spoken literature and the permanent features, especially the letters, of written literature. While the oral and aural dimensions of spoken literature are often lost when the folklorist transcribes spoken traditions into print, the artist of orature, in contrast to the folklorist, uses different typographic techniques in order to preserve the oral-aural elements of spoken literature. Following Adeeko Adeleke (1999), we can then define orature as "the creative and imaginative art of composition that relies on verbal art for communication and that culminates in performance" or at the very least appeals to readers for performance. Orature underlines the fact that the spoken and written traditions are not mutually exclusive. It lays emphasis on the transfer of aural aspects of spoken discourse to writing.

We illustrate our theory of orature, and of Pacéré as demiurge of orature in Burkinabè emerging literature, with Des entrailles de la terre. The choice of this collection to exemplify the genre of orature is due to three main reasons. First, like all of Pacéré's poems, this collection uses creative forms and techniques drawn from Moaaga spo- 
ken tradition, especially from the literature of the bendre or griot (see Pacéré 1991) on the literature of the bendre that uses zabyuya or mottos). Secondly, unlike Saglego ou le poème du tam-tam pour le Sahel ("Saglego or poem of tam-tam for the Sahel", 1994) and La poésie des griots ("Poetry of griots", 1982) in which Pacéré uses zabyuya, in this poem, the phrase tam-tam is not a zabyuure (singular form of zabyuya) per se but a composition of his own that is an imitation of the system of zabyuya. In other words, Pacéré uses the form of the poetry of tam-tam and fills it with his own words. His style appears original in this borrowing of the form from the spoken literature of the bendre to mould and convey the language of his own experience. In this sense, he is a demiurge or creator of a new style of writing. The third main reason is that Des entrailles de la terre has been overlooked by critics of Pacéré's poetry. They often focus on Pacéré's first three collections and his prize-winning collections. Des entrailles de la terre is, however, one of the collections that contains no explanatory notes; hence, a critical work on it is necessary to make it less hermetic. The present study will show how the collection presents all the characteristics of orature, namely the mixture of spoken and written tradition and of many genres.

\section{Spoken literature in print literature: Des entrailles de la terre}

Des entrailles de la terre is written in French by a writer whose mother-tongue is Mooré. After using French literal translation of Mooré terms without notice in his first three collections, in the collections that followed, Pacéré translated Mooré either in notes (e.g. in La poésie des griots), within the text (e.g. Poèmes pour l'Angola ["Poems for Angola", 1982]) or in parallel with the text (e.g. Saglego ou le poème du tam-tam pour le Sahel). One may wonder in which language (French, Mooré or the language of the bendre) Pacéré first conceives his poetry. Like Chinua Achebe and many other bilingual writers, Pacéré certainly does not know in which language he dreams or has his poetical inspiration (see Tidjani-Serpos 1986: 11-17). His poetry bears the influence of all these languages.

If one were to translate the title, Des entrailles de la terre, into Mooré, it would result in something like Têng pùuga, which in turn means two things in French. Têng pùuga can mean "city or town centre". It can also mean the "entrails of the land". Both meanings are helpful to understanding of the poem. The first meaning echoes the voice of the bendre drumming in the centre of the town or village, sending messages to the inhabitants, especially to administrative authorities. The poet in this sense is the bendre who is pleading with the Mauritanian authorities for the liberation of Tene Yousssouf Gueye and other writers to whom the collection is dedicated.

The second meaning brings the poetry closer to the ancestors who are living in the bowels of the earth where they have been laid down to rest. The bendre never forgets the ancestors during the performance of his poetry. The ancestors are always part of 
the audience at the performance of spoken literature in traditional West Africa. This literature usually takes place at evening time, a convenient time for rest and for gathering together the ancestors and the living (Chevrier 1984: 191).

The translation, "entrails of the land", can also refer to the desert where the Mauritanian writer, Tène Youssouf Gueye, is incarcerated and where Pacéré visited him. It expresses the desert as a far-flung land, another world that is different from the world of the living. One can see here an identification of the desert with the world of the ancestors: the writers in jail are waiting to enter into the world of the ancestors.

Lastly, Des entrailles de la terre ("[Ti]Teng Pùuga") can refer to the entrails or heart of the poet Titenga Pacéré himself who wholeheartedly and from the bottom of his heart pleads for the liberation of his peers and asks the ancestors for help. All these different translations and meanings show the poetry as expression of the Moaaga spoken literature of tam-tams, which gathers the living and the dead at evening time for entertaining and didactic purposes.

Des entrailles de la terre as poetry in print form is a transcription of the spoken literature of the bendre. It is spoken literature preserved in print medium. In this medium, Pacéré uses typographic devices to signal the presence of material from the spoken literature of the bendre or to provide aids for performance, since, according to Paul Valéry (1957: 1350): C'est l'éxécution du poème qui est le poème ("it is the performance of the poem that is the poem"). The use of inverted commas and different marks of emphasis (italics and bold) fulfills this function in Pacéré's poem. Quotation marks are usually used in written materials to signal spoken words or direct discourse. In Des entrailles de la terre, quotation marks are used six times, four of which are preceded by a colon, which is usually used in direct speech. They are used to introduce songs, which naturally belong to the spoken world where they are performed orally or instrumentally. The poet uses these procedures to convey the vividness of spoken literature, as in the following example:

At night

Under the tent

And the monochord guitar

The old man sings

To Oumar Ba senior,

A refrain of the elders

Heard of even in Bloomington.

"To run away from culture

To be given to partisan fights,

This is the voice that goes hoarse,

War, which makes hunger worse,

War, which divides families." (19, original emphasis) ${ }^{1}$ 
The time indicator (at night) and the actor, the old man with his guitar, singing a refrain that is passed on from generation to generation, bring the setting closer to the Moaaga traditional storytelling environment. The lexical field (guitar, sings, refrain, heard) denotes a context of spoken literature and announces the content that is separated from the written narrative by the use of inverted commas, paragraphing and a visual emphasis in italic bold characters as quotation from spoken literature. The other five examples are set apart from the rest of the narrative by the same typographic devices. The whole poem becomes thus a mixture of Moaaga traditional spoken literature with Western print medium.

Mixture can also be seen in the use of citations from written literature and zabyuya from spoken literature. At least twice in the poem, the poet refers to his poem, "Les eaux boueuses du Kadiogo" ("The muddy waters of Kadiogo") in a way that recalls the system of zabyuya. Once, speaking of his origins, he says:

I feed myself

From the muddy waters

That

Kadiogo throws away. $(45)^{2}$

Then later on, speaking to his daughter, he says:
Water runs
Like the muddy waters of
Kadiogo
To join the Niger
Or the Atlantic Ocean. (52) ${ }^{3}$

The careful reader can hardly miss these references to the poet's previous collection. The way Pacéré refers to them is meaningful. Pacéré uses only the title in the same way the bendre would use the first words of a zabyuure while addressing an audience of connoisseurs. The use of the title here is equivalent to using the first words of the whole poem, as it is the case in the papal encyclicals which draw their titles from the first words of the opening paragraphs. Well before the advent of print, in the spoken literature, the citation of the first words of a zabyuure or proverb was equivalent to quoting the full zabyuure or proverb, as Pacéré explains in the introduction to his poetry collection, Saglego ou le poème du tam-tam pour le Sahel: The zabyuure les petits tamariniers ne produisent pas quelque chose de fade ("The small tamarinier trees do not yield something insipid") is often referred to by "the small tamarinier trees" when addressing learned people (Pacéré 1994: 18). Consequently, the citation of the title, Les eaux boueuses de Kadiogo ("The muddy waters of Kadiogo"), evokes the whole poem. Pacéré transfers into printed literature a process of citation proper to Moaaga spoken literature. 
Des entrailles de la terre is replete with further references to the spoken literature of tam-tam, especially the use of zabyuya and patronymic names, as in the following lines:

\begin{tabular}{lll} 
ENGLISH & MOORÉ & FRENCH \\
\hline My origins & & Mes origines \\
\hline Trace back to the Old Land. & Tenkùdgo & Relèvent de la Vieille Terre. \\
\hline The father & Le père \\
\hline Is from the South & Est du Sud \\
\hline I conquered lands & J'ai conquis des contrées \\
\hline From the darkness & Dans l'obscurité \\
\hline Of fatherless nights. & Des nuits sans père. (45) \\
\hline
\end{tabular}

The "Old Land" or Vieille Terre is a translation from Tenkùdgo in Mooré (from Tenga = land, country and kùdgo = old), which is also a town in the south of Burkina Faso. The ancestor of the Moose, Riallé, comes from there and conquered lands from there as an Amazon separated from her father. These lines are heavily historical. Similarly, the following lines are hardly understandable if one does not know that they are literal transcriptions of personal names:

\begin{tabular}{lll} 
ENGLISH & MOORÉ & FRENCH \\
\hline A mother gives birth, & (Moaaga Chiefs) & Une mère enfante, \\
\hline She gives birth to the Mountain. [...] & Tenga & Elle enfante la Montagne. [...] \\
\hline I hear the voice & J'entends la voix & \\
\hline Who gave birth to & Qui mit au monde & La Gauche \\
\hline The Left & Goabga & Le Feu \\
\hline The Fire & Bugm & Et les Rôniers. (57) \\
\hline And the Ronier tree. & Koang
\end{tabular}

The Four chiefs whose names appear in the middle column are mentioned in this poem. Apart from his first three collections of poems, the other collections are followed by explanatory footnotes on translations of Moaaga names, words and phrases. Unexpectedly, no notes figure in this collection. Since many of the terms have already been explained in previous poems, Pacéré just puts them in bold italic characters, as above. Emphasis in bold italics is his procedure of drawing the reader's attention to literal translation. 
All these examples show that Pacéré's poetry draws from the Moaaga spoken literature as well as from the written literature of his previous collections which are used as zabyuya. The mixing of spoken literature into print literature witness to the poet's intention of making of his poetry a bridge between the two traditions, and as a written literature destined to be spoken.

Des entrailles de la terre is also shaped by the Moaaga conception of the world as a circle. Des entrailles de la terre opens and closes with this refrain:

And then,

And then;

And then,

And then! ${ }^{4}$

Even the repeated words themselves - "And then" - carry this idea of endless repetition which covers an unnoticed progress. Between the repeated refrains, innovative ideas are expressed and are smoothly integrated into the general circular structure of the culture by the rhythmic refrains. Moaaga culture is self-protective, open to welcome new ideas without being destroyed by them. The alternation between refrains and stanzas is Pacéré's technique for expressing this aspect of Moaaga cultural life.

Pacéré also uses the refrains to present Des entrailles de la terre as a collection of poems. The main refrain, which scans through the poem, gives it unity. The other refrains, which are each repeated within a portion of the poetry, present it as a collection of poems, the lines of demarcation of which are the internal refrains. Des entrailles de la terre is thus a transcription of the literature of tam-tam. Refrains and zabyuya constitute the threads that make up the fabric or text of the spoken literature of the bendre. Pacéré reproduces this text by using the same threads. Des entrailles de la terre is a weaving of the following refrains:

Man,

Man of lands,

And then,

Come to mind

From the entrails of the earth

The acid tastes

Of the stinks of the past

And

The complaints of the child. (72, see also $15,60,64,79-80,82,95-96)^{5}$

This is the main refrain (MR). It has some variants: in three places, it appears without its first two lines above ("Man, / Man of lands"), and in other places, the end is lengthened by many other verses. But in all cases, it is always recognizable as the same 
refrain. The mixture of this MR with the other internal refrains below forms the text (fabric) and frame of the whole collection.

\begin{tabular}{|c|c|c|}
\hline PAGE \# & TEXT AS WEAVING OF REFRAINS & TEXTE COMME MÉLANGE DE REFRAINS \\
\hline 15 & Main Refrain (MR) & Refrain Principal (RP) \\
\hline \multirow[t]{2}{*}{$35-38$} & Tell / Tell me that, / I cannot write / & Dis / Dis-moi que, / Je ne peux écrire, / \\
\hline & Write / A poem & Ecrire / Un poème. \\
\hline 60,64 & MR & $\mathrm{RP}$ \\
\hline $65-66$ & Woman! & Femme! \\
\hline $68-72$ & My mouth, / My mouth is full. & Ma bouche, / Ma bouche est pleine. \\
\hline 72 & MR & $\mathrm{RP}$ \\
\hline \multirow[t]{2}{*}{$72-76$} & Little girl, / Believe in God! / & Petite fille, / Crois en Dieu! / \\
\hline & Little girls / Believe in God & Les petites filles, / Croient en Dieu! \\
\hline \multirow[t]{3}{*}{$77-79$} & The tam-tam, & Le tam-tam, \\
\hline & The tam-tam is beaten & Le tam-tam est battu \\
\hline & By one hand only! & D'une seule main! \\
\hline 79 & MR & $\mathrm{RP}$ \\
\hline \multirow[t]{2}{*}{$80-82$} & The forest, & La forêt, \\
\hline & The forest is covered with stars. & La forêt est couverte d'étoiles. \\
\hline 82 & MR & $\mathrm{RP}$ \\
\hline \multirow[t]{2}{*}{$91-92$} & I believed that the sea, / The sea, I & J'ai cru que la mer, / La mer, / \\
\hline & Was salty. & Etait salée. \\
\hline $95-96$ & MR & $\mathrm{RP}$ \\
\hline
\end{tabular}

A glimpse at these refrains reveals the main ideas that are developed in the poetry. The MR shows the poet busy remembering hard realities of past life. He remembers the life of Tène Youssouf Gueye as a writer, then his wife and daughter, whom he invites to believe in God. The unusual beating of the tam-tam with one hand, which produces a monotonous sound, reflects oppression, hardships and lack of freedom of opinion. Only one voice, drummed by one hand is heard; it is the solo voice of the authorities in government. The poet compares the desert where Gueye lives to a forest covered with stars instead of trees. The MR wraps the poem from beginning to end as the table shows. The presence of secondary refrains, which suggest a compilation of poems, shows the whole poem as a collection, the refrains being the titles of poems. In this way, Pacéré's poetry challenges Western criteria of what constitutes a collection by giving the outward impression of being one long poem and yet, to those who can 
read it metaphorically, it reveals itself as a collection of poems. Pacéré mixes spoken literature and print literature.

He also combines two typographic systems: written punctuation and the punctuations of the spoken literature of tam-tams. The bendre uses refrains as full-stops for the listening audience (Pacéré 1991: 24-25). Refrains in Pacéré's poetry act as stops; indicating the beginning of new sentences or stanzas. It can then be said that Des entrailles de la terre is drawn from the spoken literature of the bendre and written in such a way that its performance should reflect the initial performance. It is mixture of spoken and print literatures as well as mixture of performing genres.

\section{Mixture of performing genres}

Des entrailles de la terre is poetry, music, story and drama, depending on the interpretations of different communities or audiences. It can be considered as poetry of the Western genre: metrical verses and rhymes appear now and then, as in the following lines:

Tout s'écoule,

Au gré des temps.

Tout s'écroule

Au gré des vents

(All flows / With the weather / All crumbles down / With the winds)

(18 also 27, my emphasis highlighting the French rhymes).

Pacéré does not use this kind of versification much in this collection. However, "Héros d'ébène" ("Ebony heroes"), (Pacéré 1976: 56-59), "Lettre à Falinga" ("Letter to Falinga"), "Message d'un soir à Manéga" (“Vesperal message in Manéga”), "Invocation” ("Invocation"), and more recently, "Il est des enfants" ("There are children"), (Kaboré 2001: 99-100, 101-102, 197, 198-203) show Pacéré's mastery of Western versification. He was influenced by the French Romantics (Châteaubriand, Alfred de Musset, Lamartine) he read in his youth. Despite his mastery of this style, he gives it up to be the demiurge of orature by showing off his genius of inventiveness and wit in finding out methods to transcribe the spoken literature of tam-tam. He succeeds in representing even the rhythm of the poetry of tam-tam in the print medium, as in these following examples:

And then,

And then;

And then,

And then!

And then come to mind, (15) 
TENE,

TENE!

TENE,

Your face will remain unknown. (18)

The head is

Higher than the body

That

Goes down

That

Goes down

That

Goes down and up, (26)

Child,

Child,

Child,

A child does not die

In the womb of his mother. (32-33)

In all these verses, the repetition of the same term or sequence many times before ending with a long verse is a powerful and successful transcription of a characteristic rhythm or rolling of the tam-tam. The reader is thus invited to performance, as orature is a performing genre.

Des entrailles de la terre is also a song that is modelled in the manner of the literature of castanets of the Manéga ensemble, which Pacéré describes in Le langage des tamtams et des masques en Afrique ("The language of tam-tams and of masks in Africa", 1991). In many instances, the reader is reminded of the presence of songs within the poetry (see 19-20, 22, 24, 27, 37, 61, 87). The following comparison highlights the similarity between Des entrailles de la terre and the chanted literature of castanets:

From the literature of castanets:

You told the truth

Man of Toéghin

You told the truth

Man of the holed ladle

You told the truth

Man of Barkoundouba

You told the truth (Pacéré 1991: 100-101)7 
From Des entrailles de la terre:

The stallions

Conquered

The lands!

The waters,

The lands!

The lightning,

The lands!

Forget

That

Land

Is land;

Forget

That

Life

Is life;

Forget

That

The crowned cranes

Have no

Land

Of exile! $(62,66 \text {, see also } 81 \text {; emphasis added })^{8}$

The two sequences are similar in the rhythmic repetition of words and phrases. The emphasized words work as a leitmotiv that is sung by a third party or audience, providing a background rhythm for the narrative of the main singer. The interaction between the performer and the audience transforms the poetry into melodrama, in the sense of play spoken to a musical accompaniment.

Indeed, the general layout of the poetry or the intercalation between paragraphs represents different roles that are played by different actors. The following is an example:

That day

The whole earth

The earth and the waters,

The whole earth was of ages.

The mountain,

Irradiated peoples! 
I left

The land of Manéga,

From karité trees to cailcedrat trees

From reeds

To dead leaves;

I left

The land;

A knell that nobody hears

Calls peoples

For

The message of the ages.

The dead are

Many on the earth.

Hillocks

Covered with down

Throw

On the sunny slopes

Violet Masks

That the slopes of mountains

Do not know

I am high

On the grass of the Savannah.

My skin

Is dark with soot

And

A thousand of my children

Embrace

The sunset. (39) 9

The left-margin stanzas ("That day [...] Irradiated people"; "The dead are [...] Do not know") develop a general theme, whereas a personal experience is told in the rightmargin stanzas ("I left [...] Message of ages"; "I am high [...] The sunset"). The first person pronoun is repeated in the latter but is absent from the former. Stanzas of the same alignment are coherent and meaningful on their own without the intercalated stanzas. This presentation of verses is a successful process by which Pacéré the playwright allocates different roles to be performed by different actors. Des entrailles de la terre is theatre, as well as poetry and music. It is thus a mixture of many performance genres. 


\section{Conclusion}

With Des entrailles de la terre we have shown Pacéré to be the demiurge or inventor of a new genre, orature, through his use of different techniques to transcribe the spoken literature of the bendre in his print literature. With devices such as spacing, layout on page and repetitions, Pacéré succeeds in translating into print form not only the rhythm of the bendre but also the different performing genres (song, drama, music) that together compose tam-tam literature. Pacéré's poetry develops the genre of orature because it is at the cusp between spoken and written traditions, being written but meant to be performed. New wine needs new wineskins. Orature as a new genre demands new literary conventions for its criticism; otherwise one is likely to come to wrong conclusions.

\section{Notes}

1. "La nuit, / Sous la tente / Et la guitare monocorde, / Le vieillard chante /A Oumar Ba, l'aîné, / Un refrain des Anciens / Entendu jusqu'à Bloomington. // 'Fuir la culture / A donner aux luttes partisanes, / C'est la voix qui s'enroue, / La guerre, qui aggrave la faim, / La guerre, qui divise les familles." (19). Hereafter all emphases are in the original unless stated otherwise and the page numbers refer to the first edition of Des entrailles de la terre.

2. "Je me nourris / Des eaux boueuses / Que / Rejette le Kadiogo" (45).

3. "L'eau coule / Comme les eaux boueuses du Kadiogo / Pour rejoindre le Niger / Ou l'Océan Atlantique" (52).

4. "Et puis, / Et puis; / Et puis, / Et puis" (15, 95-96).

5. "Homme, / Homme des contrées, / Et puis, / Me reviennent toujours, / Des entrailles de la terre, / Les goûts acides / Des puanteurs du passé, / Et / Les complaintes de l'enfant" (15, 60, 64, 72, 79-80, 82, 95-96).

6. “Et puis, / Et puis; / Et puis, / Et puis! / Et puis, me reviennent, (15); TENE / TENE, / TENE! / TENE, / Le visage restera inconnu. (18); La tête est / Plus haute que le corps / Qui / Descend, / Qui / Descend, / Qui / Descend et remonte, (26); Enfant, / Enfant, / Enfant, / Un enfant ne meurt pas / Dans le sein de sa mère" (32-33).

7. “Vous avez dit la vérité // Homme de Toéghin / Vous avez dit la vérité / Homme de la louche percée,/ Vous avez dit la vérité / Homme de Barkoundouba / Vous avez dit la vérité (Pacéré 1991: 100-101); “(I goma sida // Toege daoa / I goma sida / Sut wedg raoa, / I goma sida / Barkundub raoa / I goma sida)".

8. "Les Etalons / Ont conquis / Les contrées!/ Les Eaux, / Les contrées! / Les Eclairs, /Les contrées! // Oublie / Que / La terre / Est terre; / Oublie / Que / La vie / Est vie; / Oublie / Que / Les grues / couronnées / N'ont pas / De terre / D'exil!" (62, 66, see also 81; emphasis added).

9. “Ce jour-là / Toute la terre / La terre et les eaux, / Toute la terre était des âges. / La montagne, / Irradiait les hommes! // J'ai quitté / La terre de Manéga, / Des karités aux caïlcédrats / Des roseaux / Aux feuilles mortes; / J'ai quitté / La terre; / Un glas que nul n'entend / Appelle les hommes / Pour / Le message des âges. // Les morts sont / Nombreux sur la terre. / Des mamelons / Couverts de duvet / Jettent / Sur les flancs ensoleillés / Des Masques violets / Que méconnait le versant / Des montagnes. // Je suis haute / Sur les herbes de la savane. / Ma peau / Est noire de suie / Et / Mille de mes enfants / Embrassent / Le soleil couchant" (39).

\section{Works cited}

Adeleke, Adeeko. 1999. Micere Mugo's African Orature and Human Rights [Book review]. Research in African Literatures <www.highbeam.com/library> Accessed: 30.07.2005.

Annales de Université de Ouagadougou. 1988. Série A. Numéro spécial: Premier colloque international sur la littérature Burkinabè (décembre). Ouagadougou. 
Amoa, Urbain. 2002. Poétique de la poésie des tambours. Paris: L'Harmattan.

Chevrier, Jacques. 1984. Littérature nègre. Paris: Armand Colin.

Louguet Kaboré, Hortense. 2001. Maître Titinga Frédéric Pacéré, origine d'une vie. Paris: L'Harmattan.

Kesteloot, Lilyan. 2001. Histoire de la littérature négro-africaine. Paris: Karthala.

Mwangi, Evan. 2003. Literature: Bridging the gap between theory and practice. Lifestyle Magazine Home (Sunday, January 12). <www.nationaudio.com/News/DailyNation/Supplements/lifestyle/19012003/ story120114.htm> Accessed: 30.07.2005.

Mwangola, Mshaï S. 2003. 'Completing the Cycle: Stage to Page to Stage' in Codesria Anniversary Conference on 'Canonical Works and Continuing Innovation in African Arts and Humanities' Accra 17-19 September 2003. <www.codesria.org/Links/conferences/accra/mshai.pdf.> Accessed: 30.07.2005.

Ngugi, wa Thiong'o. 1986. Decolonizing the Mind: the Politics of Language in African Literature. London: James Currey.

Pacéré, Frédéric Titinga. n. d. Bendr $n$ gomde. (3 vols). Ouagadougou: Maison Pousga. .1976a. Ça tire sous le Sahel. Paris: P. J. Oswald.

.1976b. Refrains sous le Sahel. Paris: P. J. Oswald.

. 1976c. Quand S'envolent les grues couronnées. Paris: P. J. Oswald.

. 1982a. Poème pour l'Angola. Paris: Silex.

1982b. La poésie des griots. Paris: Silex.

1984. Du lait pour une tombe. Paris: Silex.

1986. Poème pour Koryo. Ouagadougou: Maison Pousga.

1991. Le langage des tam-tams et des masques en Afrique. Paris: L’Harmattan.

1994. Saglego ou le poème du tam-tam pour le Sahel. Ouagadougou: Fondation Pacéré.

2000. Des entrailles de la terre. Paris: L'Harmattan.

2004. Pensées africaines: proverbes, dictions et sagesse des Anciens. Paris: L'Harmattan.

Plato. 1973. Phaedrus and the Seventh and Eighth Letters. Transl. W. Hamilton. Middlesex: Penguin Books Ltd.

Ricard, Alain. 1995. Littératues d'Afrique noire: Des langues aux livres. Paris: CNRS Editions et Karthala.

Roach, Joseph. 1996. Cities of the Dead: Circum Atlantic Performance. New York: Columbia University Press.

Rousseau, Jean-Jacques. 1983. Essai sur l'origine des langues. Paris: Hatier.

Tidjani-Serpos, Nouréini. 1986. Langue du malaise, malaise de la langue: Chinua Achebe and Ngugi wa Thiong'o. Notre Librairie 84: 11-17.

Université de Ouagadougou. 1996. Mélanges Offerts à Maître Titinga Frédéric Pacéré. Paris: L'Harmattan. Valéry, Paul. 1957. CEuvres I. Paris: Gallimard.

Yépri, Léon. 1999. Titinga Frédéric Pacéré, le tambour de l'Afrique poétique. Paris: L'Harmattan. 